化が著しいため粗鉣品位維持のため必然的に切羽が分散 する傾向にある。これらを反映して切羽の集約や運搬系 統の簡素化を問題としている鉱山が多い。この対策とし ては採掘工程の向上を計り単一切羽からの出鉱量を増加 することにつきるが，このことはいいふるされてすでに 長く，鉱脈鉱山にとつてその実現がいかにむずかしいか を物語つている。以下今後開発すべき方向について私見 を述べると，岩盤の比較的堅硬な広幅鉣脈に対してはす でに対州, 鴻之舞, 豊羽等で試験されているサブレベル ・ストーピング法は今後保安面からも推進する余地があ り，採掘準備節減のためベンチの選定とガマの多い鉱脈 中の長孔穿孔発破の研究が必要であろう。

次に脈傾に変化の少ない高品位極細脈についてはかつ て足尾で試験され，今回鐘打からも提案されている大口 径さく孔による繰粉採取法も有効であり, また傾斜一定 の粘土質軟質鉱脈には切削採掘も開発の余地があるら。

低品位鉱や残鉱に対する遺利回収法として酒夋性水に よるリーチングも今後普及すると思われるが，有效な 滲透方法すなわち鉱脈の細砕方法は今後の研究課題であ る。
以上は比較的特殊な場合で，わが国脈状鉱床の大部分 を占める脈幅 $1 \mathrm{~m}$ 以下の高品位でない鉣脈の採掘につい ては，大型機械の切羽内導入にも自ら制約があり，穿孔 発破, 支保ないし浮石外し, 鉱石搔出しを繰返す彷来の 方法では大幅な工程向上を期待することはむずかしい。 かつて試験された長孔発破採掘も採掘準備に手閒がかか るわりに鉱量が少なく, 折角さく孔した長孔が鎕脈から はずれて発破に失敗する等成功をみずに終つているが， AN-FO の普及した今日，大江，鐘打両山からの半長 孔発破採掘の提案も含めてもら一度とりあげてみる必要 があろう。坑道地並からの大型さく岩機による長孔発破 に成功すれば下盤切替からの大型機械による積込みも可 能であり，また上盤の崩落しやすい切羽には上下坑道間 の上盤を一定間隔で長孔により結びこれれにイヤ・ロ 一プを通して緊ていする方法も開発されよう。

最後に現在の坑内作業全般を反省すると, 諸外国や他 産業に比べて就業時間と切羽実働時間に大幅な差が認め られるので, 今後作業環境の改善と切羽往復時閒の短縮 のために設備投資を行ない, 切羽実働時間の延長を計る 余地はありそらである。

\title{
日本における
}

\section{層状鉱床の採掘 \\ Mining of Bedded Deposits in Japan}

正会員天 野 勲 三

Kunzō AMANO
層状鉣床の採掘法は第 1 表に示すように鉣床条件によ つで種々の採掘法が採用されているが，一般的な傾向亡 しては，急傾斜で脈幅の厚い鉱床条件の鉱山では充塡式 水平段欠採掘法が，また緩傾斜で薄層の鉱床条件の鉱山 ではバーチカルスライス法が採用されている。その他上 向階段掘, 地並払, 残柱式下向採掘法, シールド枠採掘 法などを採用している鉣山もある。

\section{充填式水平段欠採掘法}

層状鉱床の鉱山ではこの採掘法がもつとも広く採用さ れている。母岩および鉙床が比較的堅硬な切羽では上向 水平段欠法が，また周囲の岩盤がもろく落盤浮石の懸念 がある切羽では下向水平段欠法が採用されている。下向 段欠法は上向段欠法に比し, 保安上の問題および跡前に 鉱石が残らないなどの点では有利であるが，坑木，爆薬

\footnotetext{
* 本会採鉱專門委員, 住友金属鉣山株式会社鉣山部
}

の使用量が多少増加する点, 緩傾斜, 細脈, 不覞則鉣体 にはむかないなどの欠点がある。

採掘区画は鉣床の条件, 切羽運搬機の種類などによつ て異なるが，上下閒隔 $25 \sim 40 \mathrm{~m}$ ，鉱体延長方向 $30 \sim 60 \mathrm{~m}$ を 1 採掘区画としている鉱山が多く，適宜の位置に上下 連絡の掘上りを開さくし人道および鉱石坑井の枠を上げ てスライム充填をしている。最近鉱石坑井に直径 $1 \mathrm{~m}$ 前 後の鉄製シニートを使用する傾向が多いようである。

穿孔は一般にエヤーレッグ方式のさく岩機が使用され 1. $0 \sim 1.8 \mathrm{~m}$ の孔深の孔が水平方向にさく岩され, 発破に は AN-FO の使用が増加しつつある。

切羽支柱は岩盤の堅硬な一部の鉱山を除き木支柱が施 されているが，日立鉣山では坑木の代替支保材として鉄 柱を使用している。

切羽での積込方法は手積, 10 20H電動スラッシャ， バケットあるいはタイヤローダなどで行なつて和り，機 
第1表 層状鉱床の採掘法一覧表

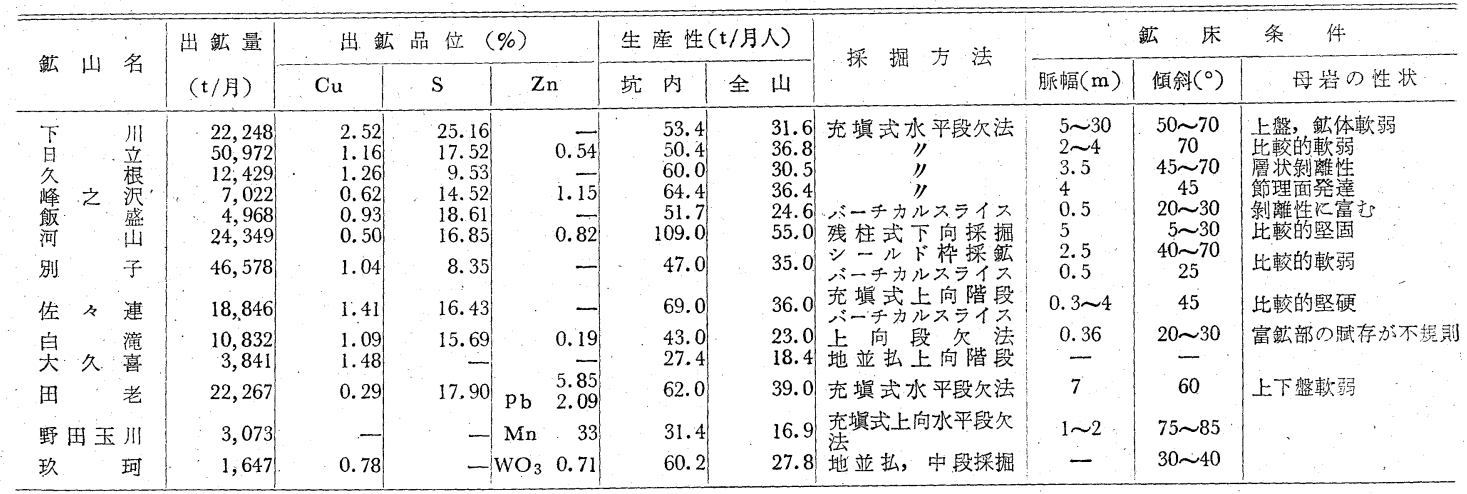

（注）生産量拉よび生産性は41年度実積

械積込による出鉣比率が増加している。

充填はほとんどの鉱山で選鉱廃石を分級したサンド、ス ライム充填が実施されているが，一部の鉱山では探鉱ズ リを充塤材として使用しているところもある。下川鉱山 では探鉱ズリを粗砕して水力充填を実施している。

生産性は鉣山の生産規模, 鉱床条件などによつて異な るが坑内人員 1 人 1 力月あたり $50 \sim 60 \mathrm{t}$ ，全山 1 人 1 力 月あたり $30 \sim 40$ 程度である。

\section{バーチカルスライス法}

緩急斜, 薄層の鉱山で採用されており，傾斜方向に30 〜 $50 \mathrm{~m}$ の切羽面をとり，エヤーレッグ方式のさく岩機で 水平方向に重放ぐりを行ない，破砕された鉱石はスラッ シャにより傾斜方向に搔下される。切羽支柱は坑木打柱 のほか,ルーフボルトを使用している鉣山もあり，採掘 跡は実木積またはズリ充填を実施している。

別子鉱山筏津坑ではこの採掘法の一変形と見られる半 長壁式鉄柱採掘を採用し切羽の集約大型化に努めてい る。

すなわち, バーチカルスライス法の坑木打柱のかわり に水圧鉄柱を傾斜方向に $0.5 \mathrm{~m}$, 走向方向に $2.0 \sim 2.5 \mathrm{~m}$ 間隔に 2 列に立柱し, 切羽面が2.0 2. $5 \mathrm{~m}$ 進行すると後 列の鉄柱を移動して跡バラシを行なつている。

\section{その他の採掘法}

河山鉱山では鉱床の規模が大きく母岩が比較的堅固で あるので残柱式無充填下向採掘法が採用されており，ま た残柱式採掘法の欠点である採掘実収率の低下を補らた め，選鉱廃石から分級されたサンドに10\%のセメントを 加えたセメントモルタルを充填し，残柱の二次採掘を行 なつている。

別子鉱山では切羽の梁部移行にともなら盤圧の増大, 切羽温度の上昇に対処するためシールド枠採掘法の試験 を実施し操業化につとめている。この採掘法は採掘区画
の上部に銿押坑道を開さくし，垂直 $60 \mathrm{~m}$ 下の坑道と銿押 切上りで結び，上部銿押坑道にシールド枠を設置し下向 きに穿孔発破を行ない, 切羽の進行にしたがつてバワー ユニットの操作によりシールド枠を下降建付して，採掘 跡は自然崩落させる方法である。試験段階では枠間から 落石防止が最大の問題点であつたが，これは枠と枠を 6 $\mathrm{mm}$ 径のワイヤロープで網状に結ぶことにより解決し た。

その後, 岩盤不良な切羽では鈗石シニートの保持が困 難であることがわかつたので，レイズボーラを導入し直 径 $1 \mathrm{~m}$ 前後の円形シニートを開さくする計画をたててい る。

\section{問題点および将来の計画}

層状鉱床は一般に平行脈の存在がすくなくまた走向 延長方向よりも鉱床落し方向への連続性が大であるた め, 採掘切羽が深部に移行する速度が速い。切羽が深部 に移行すると, 盤圧の増大, 切羽温度の上昇, 運搬コス 卜の増加, 実働時間の短縮などの問題がおこつてくる。 たとえば別子鉱山では地表下 $2,000 \mathrm{~m}$ の 26 番坑道で山鳴 り現象が現われており，また岩盤温度も次第に上昇して 最下底部の 32 番坑道では $54^{\circ} \mathrm{C}$ に達している。

盤圧の堌大に対処するためにはまず盤圧理論の解明が 必要であり, それによつて山鳴り現象の発生機構む明ら かとなり，これによつて予知，防止対策などの手掛りが 得られるであろう。坑内温度の低下のためには通気量の 増大, 安価な坑内冷却装置の開発, 切羽の集約化なごが 必要となるであろら。また運搬コストの増大，実働時間 の低下などに対処するためには, 坑内構造の合理化, 斜 ・立坑巻上速度および電車運行速度のスピード化などが 必要となるであろう。

若手労働者の確保, 坑内作業員の老令化の問題は年そ 追うにしたがつてますます深刻化するものと思われる。 これが問題解決のために流内作業環境の改善, 坑内作 
業の機械化，自動化などの必要性がより一層増大するも のと思われる。
坑木価格も引続き高騰するものと思われるので, 支保 材の鉄化, コンクリート化の推進も必要となるであるう。

\title{
日本における
}

\section{塊状鉱床の採掘 \\ Mining of Massive-ore Deposits in Japan}

\author{
正会員 奥 平 浩*
}

Hiroshi OKUDAIRA

\section{1. 序}

わが国の塊状鉸床として分類されている鉱床には，接 触交代鉱床に属寸る赤金鉱山の磁硫鉄鉱, 磁鉄鉱, 黄鉄 鉱，黄銅鉱を主体とする鉱床，大峰鉱山の黄銅鉱を主と する鈗床, 釜石鉱山の磁鉄鉱, 黄銅鉱鉱床, 都茂鉣山の責 銅鉱, 閃亜鉛鉱鉱床, 神岡, 中竜両鉱山の閃亜鉛鉱, 方 鉊鉱鉱床, 秩父鉱山の磁鉄鉱, 磁硫鉄鉱, 閃亜鉛鉱, 方 鉛釷を主成分とする鉱床, 熱水性交代鉱床に属する赤谷 鉱山の雲母鉄鉱 (赤鉄鉱を主とし, 少量の菱鉄鉱, 磁鉄 鉱を伴う), 黄銅鉱を主成分とする鉱床, 柵原鉱山の磁 硫鉄鉱，含銅硫化鉄鉱を主成分とする鉱床，虬田鉱山の 硫化鉄鉱床, 徳舜瞥, 松尾, 吾妻の硫黄鉱床等がある。

これらの鉱山で行なわれている採掘法は，それぞれの 鈗山の鉱床の規模，鉱石および上下盤の性状等の稼行条 件に忘じて，サブレベル・ストーピング，サブレベル・ ケービング, シュリンケージ, カットアンドフィル, 無 充塡地並払等, 多岐にわたり, 各鉱山の特徽を生した設 計がなされている。

各鉱山の埋蔵鉱量には大きな゙相違がある。鉱山の埋蔵 鉱量は人力の友ばざる天与のものであり，決して無限の むのではない。経済的に，安全に，乙かも有限の鉱量の 中からできるだけ多くの有用金属量を選鉱場に供給する ことが，採鉣関係業務にたずさわるものの使命である。

採掘によつて発生する空洞の大きさは，周囲の岩石ま た法右の強度に充分耐えらる範囲内でなければなら ず，上下盤および鉣石の強度がさして堅牢でなく，採掘 中に発生する空洞を保持し得ない場合には, 充填（採掘 鈗石の切羽内への一時的な買塞を含む) を伴う採掘法が 採用されている。

採掘によつて発生する空洞が自立できる場合でも，周 囲岩石または鉱石の強度に応じてその拡大しらる範囲に は自ら限界がある筈であり，一定間隔に一定大きさの鉄

* 本会採釷専門委員, 日鉄鉱業株式会社採鉱部
柱を残すことが必要になる。而してこの鉄柱の大きさ， 間隔怡鉱石，岩盤自体の強度の他，2次採掘を実施する か否かにも左右される。

以上のいかなる方法をとるにせよ，採掘空間，採掘幅 と鉱柱幅の決定が経済性, 保安上に果寸役割は大きい。

このため岩石の強度に関する研究, 検討の必要性が認 識され現場においては光弾性を応用した応力の測定装 置, ストレン・ゲージ等による応力の測定, 解析がなさ れている他, 地山内に掘さくしたボーリング孔から採取 したコアーを使つての基礎試験がなされ，採掘区画，採 掘幅と鉱柱幅の決定の指針とされている。

\section{2. 最近の新しい傾向について}

生産コストは, 生産活動に必要な工数, 各物品等の各 必要要素の原単位と単価の相类積で表わされる。したが つてこれら原単位の引下げと単価の安い資材への切替に よるコストダウンに，各鉱山とも懸命な努力を続けて いる。

塊状鉱床に打ける採鉱関倸各単位作業について，その 主なものをあげると次のとおりである。

\section{$2 \cdot 1$ 採掘}

a) AN-F O の使用：、多少の原単位の上昇は避 けられないが，低価格のため大幅な爆薬費の節減にな り，採掘費のコストダウンに大きく貢献している。

粉状で大量処理が可能であることも, 大型装填機の使 用, 運搬機と装噵機をかねたタンク車の導入を可能に し，装填能率の向上に役立つている。

b）さく岩機の大型化：独立した回転機構を備え た大型ドリフター，回転はライフル・バーで駆動される が，回転力を強力にした強力回転型ドリフター，各種操 作装置を集約した大型さく岩機 2 台を乗架したリグ等を 使つた 1 マン・2ドリル方式の採用, クローラーをたは ワゴンに登載された大型さく岩機の使用による機動力の 増大等によつて，穿孔能率は飛躍的に増大している。 